\title{
Acute Phase Proteins, Lipid Profile and Proinflammatory Cytokines in Healthy and Bronchopneumonic Water Buffalo Calves
}

\author{
${ }^{1,2}$ Sabry M. El-Bahr and ${ }^{3,4}$ Wael M. EL-Deeb \\ ${ }^{1}$ Department of Biochemistry, Faculty of Veterinary Medicine, Alexandria University, Egypt \\ ${ }^{2}$ Department of Physiology, Biochemistry and Pharmacology, \\ College of Veterinary Medicine and Animal Resources, King Faisal University, Al-Ahsa, Saudi Arabia \\ ${ }^{3}$ Department of Clinical studies, College of Veterinary Medicine and Animal Resources, \\ King Faisal University, Al-Ahsa, Saudi Arabia \\ ${ }^{4}$ Department of Veterinary Medicine, Infectious Diseases and Fish Diseases, \\ Faculty of Veterinary Medicine, Mansoura University, Mansoura, Egypt
}

Received 2012-05-06, Revised 2013-01-20; Accepted 2013-02-08

\begin{abstract}
The aim of the present study was to evaluate the diagnostic value of Acute Phase Proteins (APP), lipid profiles and proinflammatory cytokines in healthy and bronchopneumonic water buffalo calves. Therefore, sixty water buffalo calves $(9 \pm 1$ month old, $175 \pm 15 \mathrm{~kg})$ were divided into two equal groups, the first group represented healthy, control, calves whereas calves of the second group were affected with bronchopneumonia. Total leukocytic and differential counts were determined. Serum total protein, albumin, Triacylglyceol (TAG), low density lipoprotein cholesterol (LDL-c), High Density Lipoprotein cholesterol (HDL-c), Total cholesterol, Alanine Amino Transferase (ALT), Aspartate Amino Transferase (AST), Alkaline Phosphatase (ALP), Fibrinogen (Fb), Haptaglobin (Hp), Serum Amyloid A (SAA), Tumor Necrosis Factor-alpha (TNF- $\alpha$ ), Interleukins (IL1 $\beta$, IL-12) and Interferon-gamma (IFN- $\gamma$ ) were also determined. In addition, Bronchoalveolar Lavage (BAL) was collected and analyzed. The present findings indicated that, total leukocytic and neutrophils counts were significantly $(p<0.05)$ higher in pneumonic water buffalo calves compare with control. The examined biochemical parameters were significantly $(p<0.05)$ increased in pneumonic calves except for total protein, albumin, cholesterol and HDL-c which were significantly $(\mathrm{p}<0.05)$ lower compare with control. Serum concentrations of investigated APP and proinflammatory cytokines were significantly $(p<0.05)$ higher in pneumonic water buffalo calves than those of control. The present study demonstrated that, APP, lipid profile and proinflammatory cytokines perhaps served as biomarkers of bronchopneumonia in water buffalo calves. However, future studies with higher baseline sampling are still needed to establish and validate reference values for APP and cytokines in water buffalo calves.
\end{abstract}

Keywords: Haptoglobin, Fibrinogen, Serum Amyloid A, Interleukins, Biochemistry, Calves

\section{INTRODUCTION}

Respiratory diseases in bovine defined as an interaction between environmental, stressful and infectious agents (Galyean et al., 1999). Inflammation induced primarily by viral, bacterial, fungal and/or environmental factors (Wilkins, 2003; Wright et al., 2010). The primary reason of inflammation can determine the type of cellular response. Changing the concentrations of APP is an early, highly complex reaction of animal body against injurious stimuli (Gabay and Kushner, 1999; Gruys et al., 2005a) as a trial to homeostasis and restrains the microbial growth before developing acquired immunity (Gordon et al., 2008). APP are of positive (up-regulated; $\mathrm{Hp}, \mathrm{Fb}$ and SAA) or negative Egypt Tel: 0020199616621 Fax: 002452960450 
(down-regulated; albumin, transferring and $\alpha$-fetoproteins) response to the challenge (Loughmiller et al., 2007; Gabay and Kushner, 1999). This response is accompanied by alterations in lipid metabolism in the form of higher serum triglycerides and lower HDL levels (Cabana et al., 1989). Neutrophils in lungs respond to acute inflammation with a series of reactions ended by pathogen destruction (Soethout et al., 2002). These reactions involved phagocytizing pathogens, increasing antibodies, complement fixation and finally stimulate production of reactive oxygen and nitrogen (Simms and D’Amico, 1994; Segal, 2005). Moreover, Monocytes and macrophages produced proinflammatory cytokines (TNF- $\alpha$, IL1 $\beta$, IL-12 and IFN- $\gamma$ ), mediating the effect of APP, favoring T-helper cell differentiation that construct abridge between innate resistance and adaptive immunity (Guo and Ward, 2002; Trinchieri, 2003). Data concerning APP, lipid profile and proinflammatory cytokines either in clinically healthy or pneumonic water buffalo calves are lacking. Therefore, the objective of the present study was to evaluate the diagnostic values of these biomarkers in buffalo calves.

\section{MATERIALS AND METHODS}

\subsection{Animals and Sampling Protocol}

Sixty water Sixty water buffalo calves $(9 \pm 1$ month old, $175 \pm 15 \mathrm{~kg}$ ) were divided into two equal groups, the first group represented healthy, control, calves whereas calves of the second group were affected with bronchopneumonia caused by a transportation journey. The pneumonic calves showed anorexia, coughing, nasal discharge, fever and abnormal lung sound. Diagnosis based on the anamnesis, auscultation and physical examination. Blood samples were collected from the jugular vein into plain and EDTA vacationers from control and pneumonic water buffalo calves. These blood samples were collected after the onset of clinical signs which appeared 2 days post a transportation journey. Whole blood was used for the determination of total leukocytic and differential counts. Sera were harvested and stored at $-20^{\circ} \mathrm{C}$ (Schalm et al., 1975) until assayed for total protein, albumin, TAG, LDL-c, HDL-c, Total cholesterol, ALT, AST, ALP, Fb, Hp, SAA, TNF- $\alpha$, IL- $1 \beta$ and INF- $\gamma$. In addition, BAL fluid was obtained from the pneumonic calves by the Tran-tracheal aspiration method (Howard and Smith, 1999).

\subsection{Analysis of the Samples}

TLC and differential leucocytic counts were determined using electronic cell counter (VetScan HM5 Hematology system). Serum total protein, albumin, TAG, LDL-c, HDL-c and total cholesterol were determined according to the method described by Henry (1966); Doumas et al., 1981; Fossati and Prencipe (1982); Friedwald et al. (1972); Demacker et al. (1980) and Richmound (1973), respectively. VLDL-c was calculated by division of TAG/5 $\mathrm{mg} \mathrm{dL}^{-1}$ (Bauer, 1982). In addition, serum ALT, AST and ALP enzymes were measured according to the methods described by Bergmeyer and Harder (1986); Kachmar and Moss (1987) and Varley et al. (1980), respectively. $\mathrm{Fb}$ concentration in plasma was measured with a commercially available ELISA kit (USCA, Life Science) according to the manufacturer's instructions. Serum Hp was measured with a commercially available ELISA kit (Phase SAA kit, Tridelta Ltd., Ireland). SAA was measured with a commercially available ELISA kit (Phase SAA kit, Tridelta Ltd., Ireland), according to the manufacturer's instructions. IL- $1 \beta$, TNF- $\alpha$ and IFN- $\gamma$ levels were determined from undiluted serum samples using commercially available ELISA Kits (DIAsource, Diagnostic Corporation, Belgium). The plates were read at $450 \mathrm{~nm}$ on a computerized automated microplate ELISA reader (Bio TEC, ELX800G, USA). Values expressed in picograms per millilitre $(\mathrm{pg} / \mathrm{mL})$ were extrapolated using linear regression from a standard curve of known amounts of human cytokines. BAL was examined cytologically and bacteriologically. BAL samples obtained from pneumonic water buffalo calves were evaluated for the presence of intracellular organisms. The bacterial isolate were confirmed with Gram staining procedure for intracellular organisms. Bacteriological confirmation was also performed through bronchoalveolar lavage. For bacteriological testing, the BAL samples were diluted 1:10. The volume of $10 \mu \mathrm{L}$ of each diluted sample was plated onto 7\% sheep blood agar and MacConkey agar and was incubated for $24 \mathrm{~h}$ at $37^{\circ} \mathrm{C}$ in $5 \% \mathrm{CO} 2$ atmosphere (Konewan et al., 1992). The bacteria were identified according to the routine procedures (Murray, 1999).

\subsection{Statistical Analysis}

All data was presented as mean \pm standard error of mean by using student-t-test. All tests were performed using computer package of the statistical analysis system (SAS, 2002).

\section{RESULTS}

Clinical investigation of pneumonic buffalo-calves showed anorexia, coughing, nasal discharge, fever and abnormal lung sound. All pneumonic calves were characterized by similar condition/level of infection and severity. The present findings (Table 1) showed significant $(p<0.05)$ higher values of TLC and neutrophils in pneumonic calves compared with the control. 
Table 1. Hematological parameters in control $(\mathrm{n}=30)$ and pneumonic $(\mathrm{n}=30)$ water buffalo calves

\begin{tabular}{lcc}
\hline Variables & Control calves & Pneumonic calves \\
\hline TLC $\left(10^{3} / \mathrm{mm}^{3}\right)$ & $8.4 \pm 0.18$ & $15.4 \pm 0.32^{*}$ \\
Neutrophils (\%) & $29.6 \pm 0.52$ & $52.8 \pm 2.78^{*}$ \\
Lymphocytes (\%) & $55.7 \pm 1.08$ & $55.5 \pm 1.09$ \\
Esinophils (\%) & $1.9 \pm 0.06$ & $1.9 \pm 0.07$ \\
Basophils (\%) & $0.6 \pm 0.04$ & $0.6 \pm 0.03$ \\
Monocytes (\%) & $2.5 \pm 0.02$ & $2.4 \pm 0.04$ \\
\hline *Means are significantly different at the level $(\mathrm{p}<0.05)$
\end{tabular}

Table 2. Hepatic and lipid profiles in control $(\mathrm{n}=30)$ and pneumonic $(\mathrm{n}=30)$ water buffalo calves

\begin{tabular}{lcr}
\hline Variables & Control calves & Pneumonic calves \\
\hline AST (U/l) & $105.8 \pm 0.64$ & $292.0 \pm 4.88^{*}$ \\
ALT (U/l) & $88.2 \pm 0.46$ & $239.3 \pm 9.95^{*}$ \\
ALP (U/l) & $179.8 \pm 1.57$ & $269.0 \pm 5.30^{*}$ \\
Total proteins (g/dL) & $6.4 \pm 0.02$ & $5.1 \pm 0.02^{*}$ \\
Albumin (g/dL) & $3.5 \pm 0.02$ & $2.5 \pm 0.02^{*}$ \\
TG (mg/dL) & $30.2 \pm 0.73$ & $38.8 \pm 0.57^{*}$ \\
Cholesterol (mg/dL) & $60.0 \pm 1.60$ & $37.5 \pm 0.32^{*}$ \\
HDL-c (mg/dL) & $26.3 \pm 0.26$ & $17.7 \pm 0.17^{*}$ \\
LDL-c (mg/dL) & $22.4 \pm 0.67$ & $18.9 \pm 0.89^{*}$ \\
VLDL-c (mg/dL) & $6.1 \pm 0.50$ & $7.8 \pm 0.30^{*}$ \\
\hline
\end{tabular}

*Means are significantly different at the level $(\mathrm{p}<0.05)$

Table 3. Acute phase proteins and Proinflamatory Cytokines in control $(\mathrm{n}=30)$ and pneumonic $(\mathrm{n}=30)$ water buffalo calves

\begin{tabular}{lcc}
\hline Variables & Control calves & Pneumonic calves \\
\hline Haptoglobin $(\mathrm{g} / \mathrm{L})$ & $0.096 \pm 0.01$ & $1.18 \pm 0.19^{*}$ \\
Serum amyloid A $(\mathrm{mg} / \mathrm{L})$ & $23.9 \pm 0.56$ & $166.58 \pm 31.48^{*}$ \\
Fibrinogen $(\mathrm{g} / \mathrm{L})$ & $4.2 \pm 0.16$ & $16.17 \pm 1.18^{*}$ \\
TNF- $\alpha(\mathrm{ng} / \mathrm{mL})$ & $0.42 \pm 0.14$ & $2.55 \pm 0.12^{*}$ \\
IL-1 $\beta(\mathrm{pg} / \mathrm{mL})$ & $102.43 \pm 2.45$ & $640.43 \pm 20.45^{*}$ \\
IL-12 $(\mathrm{ng} / \mathrm{mL})$ & $7.45 \pm 0.67$ & $25.34 \pm 1.43^{*}$ \\
IFN- $\gamma(\mathrm{pg} / \mathrm{mL})$ & $54.76 \pm 1.56$ & $133.65 \pm 5.67^{*}$ \\
\hline
\end{tabular}

*Means are significantly different at the level $(\mathrm{p}<0.05)$

Furthermore, the values of TG, LDL-c, VLDL-c, AST, ALT and ALP were significantly $(\mathrm{P}<0.05)$ higher in pneumonic water buffalo calves when compared with control calves (Table 2). However, values of total protein, albumin, total cholesterol and HDL-c were significantly $(\mathrm{P}<0.05)$ lower in pneumonic calves than the control (Table 2). The current study (Table 3) reported significant $(\mathrm{P}<0.05)$ higher values of examined APP ( $\mathrm{Hp}, \mathrm{SAA}$ and $\mathrm{Fb})$ and proinflammatory cytokines (TNF- $\alpha$, IL-1 $\beta$, IL-12 and INF- $\gamma$ ) in the pneumonic calves compared with control. Bacteriological BAL culture revealed a presence of predominant 4 classes of microorganisms shared in induction of pneumonia in water buffalo calves. These microorganisms were Pasteurella sp., (40\%), Klebsiella sp. (20\%), E. coli
$(13.3 \%)$ and finally mixed bacterial infection represented $26.7 \%$.

\section{DISCUSSION}

The current study considered as one of the first in the field to address water buffalo bronchopneumonia by using APP, lipid profile and proinflammatory cytokines as Biomarkers. The significant $(p<0.05)$ elevation of total leucocytic and neutrophils counts in pneumonic water buffalo calves (Table 1) may be attributed to a variety of immunomodulatory effects (El-Ghmati et al., 1996). Previous studies (Howard and Smith, 1999; Soethout et al., 2002; Civelek et al., 2007) reported such increase in leucocytes in pneumonic calves. Moreover, the pathological leucocytes range was reported in several infectious diseases (Kuchler et al., 1976; LaMonica et al., 1981; Civelek et al., 2007). The significant $(p<0.05)$ elevation of ALT, AST and ALP activities and decreased liver albumin production in pneumonic water buffalo calves (Table 2) may be associated with possible hepatocellular dysfunction induced by inflammation (bronchopneumonia). Similar higher levels of ALT, AST and ALP were reported by Nikolic et al. (2006) in rats and Civelek et al. (2007) in neonatal calves. The effect of inflammation on hepatic albumin biosynthesis remains controversial (O'Leary et al., 2003). However, lower albumin level observed in the current study agrees with previous findings reported by Civelek et al. (2007). Similar marked reduction $(\mathrm{p}<0.05)$ of total cholesterol and HDL-c levels, accompanied by significant elevation $(\mathrm{p}<0.05)$ of VLDL-c and triglycerides of bronchopneumonic calves were observed in septic patients (Amersfoort et al., 2003; Fraunberger et al., 1999) and neonatal calves (Civelek et al., 2007). The reduction in serum cholesterol in pneumonic calves may be attributed either to inflammatory processes and subsequent changes in lipoprotein metabolism or liver dysfunction (Civelek et al., 2007). Lower level of HDL-c perhaps attributed to its protective effects against inflammation which mediated via bacterial endotoxines binding and subsequent neutralization (Wu et al., 2004). It was confirmed that inflammation leads to hypertriglyceridaemia in both humans and animals (Alvarez and Ramos, 1986; Phetteplace et al., 2000). This may be due to an increased production of VLDL-c, diminished conversion of VLDL-c to LDL-c by the inhibition of lipoprotein lipase activity (Gouni et al., 1993) or stimulation of hepatic and adipose tissue lipolysis as well as hepatic fatty acid synthesis, which serve as substrates for hepatic VLDL synthesis (Feingold et al., 1992). Hp is $\alpha 2$-globulin synthesized in the liver (Feldman et al., 2000) and considered as the 
major APP in ruminants. Hp could be detected in infected animals before the onset of clinical signs and that its concentration used as an indicator of disease severity (Godson et al., 1996). The increased levels of $\mathrm{Hp}$ in cattle interpreted as the outcome of tissue damage resulting from infection or inflammation (Eckersall et al., 1988). Similar results in cattle (Conner et al., 1986; Eckersall et al., 1988; Skinner et al., 1991; Saini and Webert, 1991; Heegard et al., 2000; Ganheim et al., 2003) reported the same significant $(p<0.05)$ higher levels of $\mathrm{Hp}$ of the current study (Table 3). In the contrary, other findings demonstrated either lower (Young et al., 1996) or unaltered (Wittum et al., 1996) Hp values of infected cows. The significant $(\mathrm{p}<0.05)$ elevation of SAA of pneumonic water buffalo calves (Table 3) perhaps attributed to the physiological role of SAA in host defense during inflammation (UrieliShoval et al., 2000; Murata et al., 2004; Orro et al., 2011). Recently, similar marked elevation $(\mathrm{p}<0.05)$ of SAA was reported in pneumonic calves (Nikunen et al., 2007; Orro et al., 2011). Fb is a reliable indicator of inflammation and/or bacterial infection in cattle and sheep (Pfeffer et al., 1993; Cheryk et al., 1998; Hirvonen and Pyorala, 1998; Nikunen et al., 2007; Gonzalez et al., 2008; Orro et al., 2011). The significant $(\mathrm{p}<0.05)$ elevation of $\mathrm{Fb}$ shown in the current study may be attributed to the involvement of $\mathrm{Fb}$ in homeostasis, providing a substrate for fibrin formation and in tissue repair, providing a matrix for the migration of inflammatory related cells (Thomas, 2000). Previous research demonstrated elevation of $\mathrm{Fb}$ in infected calves (Nikunen et al., 2007). Since blood samples were collected one time, the time course of APP, Lipids and cytokines were not estimated. However, it well known that, the acute phase proteins as SAA increased greater than 1000 fold in concentration within 4872 hours following inflammation in man and rabbits (Kushner, 1993). The mechanism for stimulation of APP production is by proinflammatory cytokines. The cytokine groups are the primary inducers of APP gene expression and each type initiates a different pattern of APP (Baumann and Gauldie, 1994). Thus, the increase in different patterns of APP seen in the current study reflected the production of different amounts or types of cytokines (Table 3). Similar results concerning such elevated level of TNF- $\alpha$, IL $1 \beta$ and IFN- $\gamma$ in inflammation and infection were observed in pigs (Reeth and Nauwynck, 2000) and in cattle (Pace et al., 1993; Horadagoda et al., 1994; Yoo et al., 1995; Knott et al., 1998; Morsey et al., 1999; Gruys et al., 2005b). In addition, expression of TNF and IL were significantly increased in the airways and lung lesions of infected calves (Malazdrewich et al., 2001).

\section{CONCLUSION}

The study demonstrated that, APP, lipid profile and proinflammatory cytokines perhaps served as biomarkers for the diagnosis of bronchopneumonia in water buffalo calves. However, future studies with higher baseline sampling are still needed to establish and validate reference values for APP and cytokines in water buffalo calves.

\section{ACKNOWLEDGMENT}

Authors thank the staff in Departments of Veterinary Medicine, infectious diseases and fish diseases, Faculty of Veterinary Medicine, Mansoura University and Biochemistry, Faculty of Veterinary Medicine, Alexandria University for technical assistance. The supprot of deanship of scientific research, king Faisal University is highly appreciated..

\subsection{Competing Interests}

The researchers declare that they have no competing interests.

\section{REFERENCES}

Alvarez, C. and A. Ramos, 1986. Lipids, lipoproteins, and apoproteins in serum during infection. Clin. Chem., 32: 142-145. PMID: 3940695

Amersfoort, E.S.V., T.J.C.V. Berkel and J. Kuiper, 2003. Receptors, mediators and mechanisms involved in bacterial sepsis and septic shock. Clin. Microbiol. Rev., 7: 379-414. DOI: 10.1128/CMR.16.3.379414.2003

Bauer, J.D., 1982. Clinical Laboratory Methods. 9th Edn., Mosby, ISBN-10: 0801605083, pp: 1235.

Baumann, H. and J. Gauldie, 1994. The acute phase response. Immunol. Today, 15: 74-80. PMID: 7512342

Bergmeyer, H.U. and M. Harder, 1986. A colorimetric method of the determination of serum glutamic oxaloacetic and glutamic pyruvic transaminase. Clin. Biochem., 24: 481-481.

Cabana, V.G., J.N. Siegel and S.M. Sabesin, 1989. Effect of the acute phase response on the concentration and density distribution of plasma lipids and apolipoproteins. J Lipid Res., 30: 39-49. PMID: 2493057 
Cheryk, L.A., K.E. Hooper-Mcgrevy and P.A. Gentry, 1998. Alterations in bovine platelet function and acute phase proteins induced by Pasteurella haemolytica A1. Can. J. Vet. Res., 62: 1-8. PMID: 9442932

Civelek, T., K. Kav, I. Camkerten, A.H. Celik and A. Acar, 2007. Effect of bacterial pneumoniain neonatal calves on serum lipids. Bull. Vet. Inst. Pulawy, 51: 503-507.

Conner, J.G., P.D. Eckersall, M. Doherty and T.A. Douglas, 1986. Acute phase response and mastitis in the cow. Res. Vet. Sci., 41: 126-128. PMID: 3489967

Demacker, P.M., H.E. Von-Janssen, A.M. Hifman, A.V. Lear and A.P. Jansen, 1980. Measurement of highdensity lipoprotein cholesterol in serum: Comparison of six isolation methods combined with enzymic cholesterol analysis. Clin. Chem., 26: 1780-1786. PMID: 6777082

Doumas, B.T., D.D. Bayse, R.J. Carter, T. Jr. Peters and R. Schaffer, 1981. A candidate reference method for determination of total protein in serum. I. Development and validation. Clin. Chem., 27: 16421650. PMID: 6169466

Eckersall, P.D., H., Parton and J.G.Conner, 1988. Acute Phase Reactants in Diseases of Dog and Cattle. In: Animal Clinical Biochemistry: The Future, Blackstone, D.J. and P.D. Eckersall (Eds.), Cambridge University Press, Cambridge, ISBN-10: 0521355184, pp: 225-228.

El-Ghmati, S.M., E.M.V. Hoeyveld, J.G.V. Strijp, J.L. Ceuppens and E.A. Stevens, 1996. Identification of haptoglobin as an alternative ligand for CD11b/CD18. J. Immunol., 156: 2542-2552. PMID: 8786317

Feingold, K.R., I. Staprans and R.A. Memon, 1992. Endotoxin rapidly induces changes in lipid metabolism that produce hypertriglyceridemia: Low doses stimulate hepatic triglyceride production while high doses inhibit clearance. J. Lipid Res., 33: 17651776. PMID: 1479286

Feldman, B.F., J.G. Zinkl and N.C. Jain, 2000. Schalm's Veterinary Hematology. 5th Edn., Blackwell, ISBN10: 0683306928 , pp: 1344.

Fossati, P. and I. Prencipe, 1982. Serum triglyceride determination colorimetrically with an enzyme that produce hydrogen peroxide. Clin. Chem., 28: 20772083. PMID: 6812986

Fraunberger, P., S. Schaefer and K. Werdan, 1999. Reduction of circulating cholesterol and apolipoprotein levels during sepsis. Clin. Chem. Lab. Med., 37: 357-362. PMID:10353483
Friedwald, W.T., R.T. Levy and D. S. Fredrickson, 1972. Estimation of the concentration of low density lipoprotein cholesterol in plasma without use of the preparative ultracentrifuge. Clin. Chem., 8: 499-505.

Gabay, C. and I. Kushner, 1999. Acute-phase proteins and other systemic responses to inflammation. N. Engl. J. Med., 340: 448-454. PMID: 9971870

Galyean, M.L., L.J. Perino and G.C. Duff, 1999. Interaction of cattle health/immunity and nutrition. J. Anim. Sci., 77:1120-1134. PMID: 10340578

Ganheim, C., C. Hulten, U. Carlsson, H. Kindahl and R. Niskanen et al., 2003. The acute phase response in calves experimentally infected with bovine viral diarrhoea virus and/or Mannheimia haemolytica. J. Vet. Med. 50: 183-190. PMID: 12916692

Godson, D.L., M. Campos, S.K Attah-Poku, M.J. Redmond and D.M. Cordeiro et al., 1996. Serum haptoglobin as an indicator of the acute phase response in bovine respiratory disease. Vet. Immunol. Immunopathol., 51: 277-292. DOI: 10.1016/0165-2427(95)05520-7

Gonzalez, F.H.D., F. Tecles, S. Martınez-Subiela, A. Tvarijonaviciute and L. Soler et al., 2008. Acute phase protein response in goats. J. Vet. Diagn. Invest., 20: 580-584. PMID: 18776089

Gordon, B., E. Mary, S. Megan and L. Jeff, 2008. Stress alters the cellular and proteomic compartments of bovine bronchoalveolar lavage fluid. Vet. Immunol. Immunopathol., 125: 111-125. DOI: 10.1016/j.vetimm.2008.05.005

Gouni, I., K. Oka and J. Etienne, 1993. Endotoxininduced hypertriglyceridemia is mediated by suppression of lipoprotein lipase at a posttranscriptional level. J. Lipid Res., 4: 139-146. PMID: 8445338

Gruys, E., M.J. Toussaint, N. Upragarin, E.A. Van and A.A. Adewuyi et al., 2005a. Acute phase reactants, challenge in the near future of animal production and Veterinary medicine. J. Zhejiang Univ. Sci., 6: 941-947. DOI: 10.1631/jzus.2005.B0941

Gruys, E., M.J.M. Toussaint, T.A. Niewold and S.J. Koopmans, 2005b. Acute phase reaction and acute phase proteins. J. Zhejiang Univ. Sci., 6: 1045-1056. DOI: 10.1631 jzus.2005.B1045

Guo, R.F. and P.A. Ward, 2002. Mediators and regulation of neutrophil accumulation in inflammatory responses in lung: Insights from the IgG immune complex model. Free Radic. Biol. Med., 33: 303-310. PMID: 12126752 
Heegard, P.M.H., D.L. Godson, M.J.M. Toussaint, K. Tiornehoj and L.E. Larsen et al., 2000. The acute phase response of haptoglobin and Serum Amyloid A (SAA) in cattle undergoing experimental infection with bovine respiratory syncytial virus. Vet. Immunol. Immunopathol., 77: 151-159. PMID: 11068073

Henry, R.J., 1966. Clinical Chemistry. 1st Edn., Harper and Row Publishers, New York.

Hirvonen, J. and S. Pyorala, 1998. Acute-phase response in dairy cows with surgically-treated abdominal disorders. Vet. J., 155: 53-61. DOI: 10.1016/S10900233(98)80036-1

Horadagoda, A., P.D. Eckersall and J.C. Hodgson, 1994. Immediate responses in serum TNF (alpha) and acute phase protein concentrations to infection with Pasteurella haemolytica A1 in claves. Res. Vet. Sci., 57: 129-132. DOI: 10.1016/00345288(94)90094-9

Howard, J.L. and R.A. Smith, 1999. Current veterinary therapy 4: Food Animal Practice. 4th Edn., WB Saunders Company, Philadelphia, ISBN-10: 0721676545, pp: 766.

Kachmar, J. F. and D.W. Moss, 1987. Enzymes. In: Fundamentals of Clinical Chemistry, Tiez, N.W. (Ed.), W.B. Saunders Co., Philadelphia PA., ISBN10: 0721688624, pp: 666-672.

Knott, I., V. Weynants, K. Walravens, W.H.M.V.D. Poel and J.A. Kramps et al., 1998. Immune response of calves experimentally infected with non-cellculture-passaged bovine respiratory syncytial virus. Arch. Virol., 143: 1119-1128. DOI: 10.1007/s007050050360

Konewan, E.W., S.D. Allen, W.M. Janda, P.C. Schreckenberger and W.C. Winn Jr, 1992. Color Atlas and Textbook of Diagnostic Microbiology. 4th Edn., Lippincott, Philadelphia, ISBN-10: 0397512015 , pp: 1154.

Kuchler, H..H. Fricker and E.Gugler, 1976. Blood picture in the early diagnosis of neonatal septicemia. Helv. Paediatr. Acta., 31: 33-46. PMID: 939698

Kushner, I., 1993. The Acute Phase Response and the Erythrocyte Sedimentation rate. In: Textbook of Rheumatology, Kelley, W.N., E.D. Harris, S. Ruddy and C.B. Sledge (Eds.), W.B. Saunders Company, Philadelphia, PA., ISBN-10: 0721631576, pp: 669-676.

LaMonica, C.R., M. Blackston and R.B. Dawson, 1981. Acute renal failure associated with the thrombocytopenia of septicemia. Adv. Shock Res., 6: 75-79. PMID: 6760708
Loughmiller, J.A., S.S. Dritz, J.L. Nelssen, M.D. Tokach and R.D. Goodband et al., 2007. Effects of salmonella typhimurium challenge on swine growth, nitrogen balance, insulin-like growth factor-i and acute phase proteins. Am. J. Anim. Vet. Sci., 2: 1122. DOI: 10.3844/ajavsp.2007.11.22

Malazdrewich, C., T.R. Ames, M.S. Abrahamsen and S. K. Maheswaran, 2001. Pulmonary expression of tumor necrosis factor alpha, interleukin-1 beta and interleukin- 8 in the acute phase of bovine pneumonic pasteurellosis. Vet. Pathol., 38: 297-310. DOI: $10.1354 /$ vp.38-3-297

Morsey, M.A., A.G. van Kessel and Y. Mori, 1999. Cytokine profiles following interaction between bovine alveolar macrophages and Pasteurella haemoloytica. Microb. Pathog., 26: 325 331.DOI: 10.1006/mpat.1999.0274

Murata, H., N. Shimada and M. Yoshioka, 2004. Current research on acute phase proteins in veterinary diagnosis: an overview. Vet. J., 168: 28-40. DOI: 10.1016/S1090-0233(03)00119-9

Murray, P.R., 1999. Manual of Clinical Microbiology. 7th Edn., DC ASM Press, Washington, ISBN-10: 1555811264, pp: 1773.

Nikolic, J., I. Stojanovic and R. Pavlovic, 2006. The role of Larginine in toxic liver failure: interrelation of arginase, polyamine catabolic enzymes and nitric oxide synthase. Amino Acids, 32: 127-131. DOI: 10.1007/s00726-006-0309-y

Nikunen, S., H. Hartel, T.Orro, E. Neuvonen and R. Tanskanen et al., 2007. Association of bovine respiratory disease with clinical status and acute phase proteins in calves. Comp. Immunol. Microbiol. Infect. Dis., 30: 143-151. DOI: 10.1016/j.cimid.2006.11.004

O’Leary, M.J., M. Koll and C.N. Ferguson, 2003. Liver albumin synthesis in sepsis in the rat: influence of parenteral nutrition, glutamine and growth hormone. Clin. Sci., 105: 691-698. PMID: 12875649

Orro, T., T. Pohjanvirta, U. Rikula, A. Huovilainen, S. Alasuutari, L. Sihvonen, S. Pelkonen and T. Soveri, 2011. Acute phase protein changes in calves during an outbreak of respiratory disease caused by bovine respiratory syncytial virus. Comp. Immunol. Microbiol. Infect. Dis., 34: 23-29. DOI: 10.1016/j.cimid.2009.10.005

Pace, L., J.M. Kreeger and K.L. Bailey, 1993. Serum levels of tumor necrosis factor-(alpha) in calves experimentally infected with Pasteurella haemolytica Al. Vet. Immunol. Immunopathol., 35: 353-364. DOI: 10.1016/0165-2427(93)90044-5 
Pfeffer, A., K.M. Rogers, L. O’Keeffe and P.J.Osborn, 1993. Acute phase protein response, food intake, live weight change and lesions following intrathoracic injection of yeast in sheep. Res. Vet. Sci., 55: 360-366. PMID:7506837

Phetteplace, H.W., N. Sedkova and K.I. Hirano, 2000. Escherichia coli sepsis increases hepatic apolipoprotein B secretion by inhibiting degradation. Lipids, 35: 1079-1085. DOI: 10.1007/s11745-000-0622-y

Reeth, K.V. and H. Nauwynck, 2000. Proinflammatory cytokines and viral respiratory disease in pigs. Vet. Res., 31: 187-213. PMID: 10779199

Richmound, W., 1973. Preparation and properties of cholesterol oxidase from Nacardia sp. and its application to enzymatic assay of total cholesterol in serum. Clin. Chem., 19: 1350-1356.

Saini, P.K. and D.W. Webert, 1991. Application of acute phase reactants during antemortem and postmortem meat inspection. J. Am. Vet. Med. Assoc., 198: 1898-1901. PMID: 1714890

SAS, 2002. Statistical Analysis System. 1st Edn., SAS Institute Inc., Cary, NC, USA.

Schalm, O.W., N.C. Jain and E.J. Carroll, 1975. Veterinary Hematology. 3rd Edn., Lea and Febiger, Philadelphia, ISBN-10: 0812104706, pp: 807.

Segal, A.W., 2005. How neutrophils kill microbes. Annu. Rev. Immunol., 23: 197-223. DOI: 10.1146/annurev.immunol.23.021704.115653

Simms, H.H. and R. D'Amico, 1994. Regulation of intracellular polymorphonuclear leukocyte $\mathrm{Fc}$ receptors by lipopolysaccharide. Cell. Immunol., 157: 525-541. DOI: 10.1006/cimm.1994.1247

Skinner, J.G., R.A. Brown and L. Roberts, 1991. Bovine Haptoglobin response in clinically defined field conditions. Vet. Rec., 128: 147-149. PMID: 1903006

Soethout, E. C., K. E. Muller and V. P. Rutten, 2002. Neutrophil migration in the lung: General and bovine-specific aspects. Vet. Immunol. Immunopathol., 87: 277-285. DOI: 10.1016/S01652427(02)00053-3

Thomas, J.S., 2000. Overview of Plasma Proteins. In: Schalm's Veterinary Hematology, Feldman, B.F., J.G. Zinkl and N.C. Jain (Eds.), Lippincott Williams, Wilkins, Philadelphia, pp: 891-898.
Trinchieri, G., 2003. Interleukin-12 and the regulation of innate resistance and adaptive immunity. Nat. Rev. Immunol., 3: 133-146. DOI: 10.1038/nri1001

Urieli-Shoval, S., R.P. Linke and Y. Matzner, 2000. Expression and function of serum amyloid A, a major acute-phase protein, in normal and disease states. Curr. Opin. Hematol., 7: 64-69. PMID: 10608507

Varley, H., A. Gewenlock and M. Bell, 1980. Practical Clinical Biochemistry. 5th Edn., Williams Heinemen Medical Books, London, pp: 741.

Wilkins, P.A., 2003. Lower respiratory problems of the neonate. Vet. Clin. North Am. Equine Pract., 19: 1933. PMID: 12747659

Wittum, T.E., C.R., Young, L.H. Stanker, D.D. Griffin and L.J. Perino et al., 1996. Haptoglobin response to clinical respiratory tract disease in feedlot cattle. Am. J. Vet. Res., 57: 646-649. PMID: 8723875

Wright, H.L., R.J. Moots, R.C. Bucknall and S.W. Edwards, 2010. Neutrophil function in inflammation and inflammatory diseases. Rheumatology, 49: 1618-1631. DOI: 10.1093/rheumatology/keq045

Wu, A., C.J. Hinds and C. Thiemermann, 2004. Highdensity lipoproteins in sepsis and septic shock: Metabolism, actions and therapeutic applications. Shock, 21: 210-221. PMID: 14770033

Yoo, H.S., S.K. Maheswaran, S. Srinand, T.R. Ames and M. Suresh, 1995. Increased tumour necrosis factor- $\alpha$ and interleukin- $1 \beta$ expression in the lungs of calves with experimental pneumonic pasteurellosis. Vet. Immunol. Immunopathol., 49: 15-28. PMID: 8588337

Young, C.R., T.E. Wittum, L.H.Stanker, L.J. Perino and D.D. Griffin et al., 1996. Serum haptoglobin concentrations in a population of feedlot cattle. Am. J. Vet. Res., 57: 138-141. PMID: 8633796 